\title{
Multicentric reticulohistiocytosis
}

INSERM

\section{Source}

INSERM. (1999). Orphanet: an online rare disease and orphan drug data base.

Multicentric reticulohistiocytosis. ORPHA:139436

Multicentric reticulohistiocytosis (MRH) is a rare non-Langerhans cell histiocytosis

characterized by the association of specific nodular skin lesions and destructive arthritis. 